\title{
Why the Implementation of the Clean-Up (Saberpungli) Policy for Illegal Levies has not yet Reached the Target in East Java
}

\author{
Zakariya $^{1}$, Teguh Santoso ${ }^{2}$, Samsul Arifin ${ }^{3}$, Taufillah Ifada ${ }^{4}$, May Yusita Sari ${ }^{5}$ \\ ${ }^{1}$ Departement of Public Administration, Faculty of Social Science and Political Science, Universitas 17 Agustus \\ 1945 Surabaya (email: zakaria@untag-sby.co.id), ${ }^{2}$ Departement of Public Administration, Faculty of Social Science \\ and Political Science, Universitas 17 Agustus 1945 Surabaya (email: teguh@untag-sby.co.id) \\ ${ }^{3}$ Departement of Public Administration, Faculty of Social Science and Political Science, Universitas 17 Agustus \\ 1945 Surabaya (email: samsularifin2003@gmail.com), ${ }^{4}$ Departement of Public Administration, Faculty of Social \\ Science and Political Science, Universitas 17 Agustus 1945 Surabaya (email: Fadaifada98@gmail.com), \\ ${ }^{5}$ Departement of Public Administration, Faculty of Social Science and Political Science, Universitas 17 Agustus \\ 1945 Surabaya (email: mayyusitasari@gmail.com)
}

\begin{abstract}
Since the issuance of Presidential Regulation No. 87 of 2016 concerning the task force to clean up illegal levies (Saberpungli), as a manifestation of Jokowi's commitment to the nine ideals (nawacita) that have been scheduled by the Jokowi government, especially related to the goal of strengthening the country's presence in conducting corruption-free, dignified and reliable system reform and law enforcement has been followed up by the provincial government. The province of East Java is no exception. The East Java government has made a Sweep-Off Task Force for Illegal Levies with the issuance of the Governor's policy No. 188/624 / KTPS / 013/2016. The implementation of the Governor's regulation has not been effective and efficient because the capture operation in its implementation only targets illegal levies valued at Rp. 10.00 - Rp. 100,000, while the legal process in each case costs between Rp. 50,000,000 to Rp. 100,000, - In addition, when a suspect acts to serve public activities, public service activities are hampered. For example educators, paramedics and others. The research question is Why The Implementation of the clean-up policy for illegal levies has not yet reached the target in East Java? This study uses a qualitative method approach by exploring information from key informants involved in implementing Saberpungli's policies, namely from the inspectorate, prosecutor's office and police as the main data and related documents. The results of the study show that the implementation of the clean-up policy in East Java was not able to reach the target due to five factors. First, coordination between task forces is still weak. Second, the lack of support from the regional government budget in other levies. Third, there is no SOP that the implementing agency can agree on and understand. As for recommendations that the implementation of the clean-up policy of illegal levies can reach the target, it is necessary to demonstrate the commitment of the provincial government by budgeting appropriately and need to increase coordination with the SOP as a shared direction in eradicating the practice of illegal collection in the public sector.
\end{abstract}

\section{Keywords:}

clean-up policy - Illegal levies 


\section{Introduction}

Development is a process of change that takes place in a planned, integrated and sustainable manner with the main goal being to improve the welfare of human life or the community of a nation. Development always moves from an unfavorable life condition to a better life in order to achieve the national goals of a nation. National development aims to realize a just and prosperous society that is materially and spiritually evenly based on the Pancasila and the 1945 Constitution of the Republic of Indonesia. In order to achieve its objectives, the Government has compiled programs, targets and activities as guidelines in dealing with 3 (three) main problems of the nation, namely (1) the decline in the country's authority, (2) the weakening of the joints of the national economy, and (3) the intolerance and crisis of the nation's personality. Nawacita as 9 (Nine) President Joko Widodo's and Vice President Jusuf Kalla's priority agenda was formulated as a path of change towards a politically sovereign, independent economy and personality. 9 (Nine) priority agenda are: Bringing back the State to protect the entire nation and provide a sense of security to all citizens. 1. Building clean, effective, democratic and trusted governance. 2. Building Indonesia from the periphery by strengthening regions and villages within the framework of the Unitary State. 3. Strengthening the presence of the State in reforming systems and law enforcement that are free of corruption, dignified and trusted. 4. Improving the quality of life of Indonesian people. 5. Increase people's productivity and competitiveness in international markets. 6 . Achieve economic independence by moving the strategic sectors of the domestic economy. 7. Revolutionizing the nation's character. 8. Strengthening diversity and strengthening Indonesian social restoration.

Illegal levies on public services will disrupt and burden the community so that it can eliminate public trust in the government, hamper economic development, can affect the investment climate and deteriorate legal authority. The high level of service uncertainty as a result of long and tiring service procedures is the cause of the increasing number of people who give up when dealing with corrupt public services. This is one of the factors that causes people to tend to be more tolerant of the practice of extortion in the administration of public services. In general, illegal levies are the imposition of fees or levies at places or activities that should not have additional costs / fees, so that they can be interpreted as an activity of collecting fees or forcibly asking money by someone to another party and it is a practice of 
crime or criminal activity. In the modus operandi, the extortion agent is usually followed by acts of violence, threats of violence, complicating the process, buying time, asking for compensation to those who are in a weak or served position. That is why extortion tends to lead to extortion and coercion which in criminal law is a prohibited act or a criminal offense. Based on records from the United Nations documents on efforts to eradicate corruption, illegal levies are illegal levies, requests, receipt of all payments, gifts or other benefits, directly or indirectly, by public officials or representatives chosen from a country from a private company or the public including transnational companies or individuals from other countries that are associated with the intention to perform or not perform a task related to an international commercial transaction. Acts carried out by public servants or state administrators with the intention of benefiting themselves or others as a person against the law contained in the formulation of Article 12 letter e, and Article 12 letter $\mathrm{f}$ in Law Number 31 of 1999 amending the Law Number 20 of 2001 concerning Corruption Crimes. On the basis of the above phenomenon, the problem formulation of this research is why the implementation of the levies sweep policy in east java has not reached the target? furthermore, the purpose of this study is to analyze why the implementation of the clean sweeping policy sweep in east java has not reached the target. Research conducted by Dewa Jaya Ferogusta, in 2009 with the title Supervision of Drivers or Freight Companies Based on Law Number 22 Year 2009 concerning Road Traffic and Transport (Study on the Pontianak Weigh Bridge in the Weighing Bridge of Pontianak) using the method of sociological normative legal research obtained findings as follows: that based on data obtained that violations of violations that occur against the provisions of the transportation of goods cargo by drivers of public goods vehicles are indeed decreasing, but the number of violations that occur at the Timbang Batu Layang Bridge is still high, which means that shows that supervision of the transportation of goods in Batu Weigh Bridge in Pontianak City is not yet optimal. Whereas in the case of overcoming the causes of the overload of goods transported by public goods transport vehicles, among others, preventive measures are to routinely conduct raids or inspections coordinated together with DLLAJ members, especially for public goods transport vehicles which are allegedly violating the provisions concerning the rules standardization of transportation of goods by public goods transport vehicles. In a repressive manner, against drivers of public goods transport vehicles caught 
red-handed committing violations as referred to above, then the authorized officer will be given data and will then be given a warning or reprimand so as not to make the same mistake and if the next inspection is caught again then the driver acted and processed in accordance with applicable regulations. That the factors become an Obstacle in the Implementation of Oversight Overloading by Drivers or Public Transport Companies of Goods in the Pontianak Weigh Bridge weighbridge by related institutions. Research from Pasaribu, Hiras in 2009 with the title Influence of Commitment, Perception, and Application of the Basic Pillars of Managerial Management Toatal Quality (Survey on Manufacturing SOEs in Indonesia) that aims to find the effect of top management commitment and perceptions of division managers regarding TQM and the application of the basic pillars of total quality management (TQM) to managerial performance in manufacturing SOEs in Indonesia using the population survey method of 28 manufacturing SOEs in Indonesia. The data used consisted of primary data obtained through questionnaires and secondary data that supported the research. Hypothesis testing is done using Path Analysis. Based on the results of the study it was found that: (1) There is a correlation between the commitment of top management, perceptions of division managers regarding TQM, and the application of the basic pillars of TQM in manufacturing SOEs in Indonesia; (2) Simultaneously and partially the commitment of the top leadership, the perceptions of division managers regarding TQM, and the application of the basic pillars of TQM affect managerial performance.

Research conducted by Deyv Ch. Rumambi in 2014 entitled Corruption in the Perspective of State Administrative Law, with the aim to find out how the existence of corruption in the perspective of state administrative law and how to eradicate corruption in the perspective of State administrative law. The research method used is a normative juridical research method. The results of his research are 1 . Corruption in the name of public policy, whether issued by legislative bodies, executives, or decision-making institutions in State-Owned Enterprises (BUMN) or Regional-Owned Enterprises (BUMD) and also banking institutions are the most sophisticated modus operandi of corruption. As a legal subject, as the bearer of rights and obligations, government officials can take legal actions based on their ability or authority. 2. The strategy of eradicating corruption in the perspective of state administrative law covers several areas of change, which are as follows: 
good leadership or governance; public programs where changes to public programs will reduce incentives to give bribes and reduce the number of transactions and increase opportunities for citizens to get public services; improvement of government organizations where changes are needed to the way the government carries out its daily tasks; law enforcement.

\section{Methods}

Researchers in carrying out and completing research have used this type of qualitative research. This is where the researcher does this by basing on Moeloeng's opinion, which states that: This type of qualitative research is an attempt to answer the problems raised. Qualitative research places more emphasis on efforts to answer the meaning that lies behind reality and is revealed through collected data, (Moleong, 2002). The research approach used is a case study research with an emphasis on the case implementation of the Wild Sweeping Clean Sweeping policy in East Java in the context of public policy implementation studies. This is by the researcher based on the explanation from Cresswell that: There are five types of research namely, biography, phenomenology, grounded theory, ethnography and case studies. (Cresswell, 2014). This study uses a qualitative method approach by exploring information from key informants involved in implementing Saberpungli's policies, namely from the inspectorate, prosecutor's office and police as the main data and related documents.

\section{Results and Discussion}

The coordination factor in implementing the Saber Pungli policy in East Java implemented by all elements contained inhibiting and supporting factors. Things can be seen below. "Coordination carried out on Saber extortion in East Java with the Regional Police is always carried out based on the invitation letter, whereas the obstacle, if the Chairwoman invited, but the representative was present, and there were also obstacles that existed in the Illegal or UPP Eradication Unit both Regency and City, that this happened because it was related to the Budget and lack of coordination. But the problem of other factors that can support a lot. With good communication between relevant agencies, for handling, which cases must be handled by APIP and also which cases are handled by Law 
Enforcement Officers, only after that all will be able to proceed to further processing ". (Source, interview with Inspecturat General of East Java, August 2018)

Regarding this resource Saber Pungli East Java already has it which can be demonstrated through the following interview. "Resources in the form of a budget as supporting Saber extortion include those in the East Java Saber Extortion Guidelines. Which is the East Java Province Illegal Eradication Unit supported by a budget from the East Java Province APBD, in the form of grants totaling three billion rupiah used for six Working groups, which is up to months September 2018, it was absorbed to the fullest. "(Source, interview with Inspector General of East Java, August 2018). The budget for the East Java Regional Police in the form of grants from the law firm of the East Java Provincial Secretariat was Rp. 3 billion and absorbed by Rp. $682,846,968$ or 22.76 percent of the total budget provided. This means that in addition to a small budget but the seriousness to conduct operations is also low.

Understanding the general purpose of a standard and policy objective is important. Successful policy implementation, can be frustrated when officials (officials), are not fully aware of the standards and objectives of the policy. In terms of Saber Pungli East Java standards, they already have it, as seen in the results of the interview with the implementor as follows, "Our guidelines are very clear, it is in general legislation, but the most lex specialy is specifically regulated in Presidential Regulation no. 87 of 2016, which is about the formation of the saber extortion task force, more specifically it is in the East Java Governor's Decree Number 188/222 / kpts / 013/2018 on 29 March 2018. Going now is enough. " Source, Interview with Chief Chair of the Illegal Eradication Unit, 2018) Standards and policy objectives have a close relationship with the disposition of implementers. The direction of the disposition of implementers (implementors) to the standards and policy objectives is also a "crucial" thing. Implementors may fail in implementing the policy, because they reject or do not understand what is the purpose of a policy. In terms of the objectives of the implementation of Saber Pungli East Java already has the targets that appear in the following interview, the targets in Saber Pungli in East Java are shown by the data generated from the interview as referred to below. "The target of the extortion saber is none other than, first, to help the local government in increasing local revenue (PAD), why? because at this time there is a lot of leakage of regional income everywhere, so that income does not come in 
full to the government, for example, local taxes, fees, permits, and much more. Now the second, the target of this extortion saber is to improve the discipline of the state apparatus in service to the public through transparency and standardization of services, this is in accordance with statutory regulations and eliminating illegal levies. Thirdly, building and internalizing an anti-extortion culture and corruption in governance and society. "(Source, Interview with the Chairperson of the Illegal Eradication Unit Implementing Unit, 2018)

Regarding the disposition in the Saber Pungli program in East Java which is a factor of these obstacles and supporters as can be shown through the interview below. "Disposition of the implementation of Saber Pungli in East Java, the inhibiting factor is the case of the descent from IRWASDA which was disseminated to Crimsus, and then from the Crimsus implementing Catch Hands Operation (OTT), this is another OTT you know, not the Saber Pungli, so here is not just the Saber Pungli OTT case, but there are also other OTT cases. Now that's what makes it like this. Finally, the OTT Saber Pungli is declining, right? But also this disposition has its supporters. Supporting that is optimizing the utilization of personnel. There is more to optimize the use of Work Units, and optimize the use of infrastructure facilities, which are located in the regional government, so that it can all implement Saber Extortion in East Java, and can carry out eradication of illegal levies effectively and efficiently ". (Source, interview with Inspector General of East Java, August 2018).

\section{Conclusion}

Budget efficiency needs to be done by means of illegal levies not included in corruption but general criminal acts. This is in line with the explanation from the East Java Regional Police Irwasda when giving information to the East Java Provincial Illegal Eradication Eradication Coordination Unit, stating that the results of the Capture of Operations up to July 2017 were 88 cases with 174 suspects and the amount of evidence in the amount of Rp. . 3,883,045,500. As for the progress of the results of the Operation Catch Hands can be seen as follows: for P-21 as many as 28 cases (19 LP Splitsing). For those in the investigation process there were 60 cases, while those submitted by APIP were 3 cases. Related to the allocation of Village Funds and Village Funds as many as 4 cases and those related to Prona as many as 11 cases. 16 cases related to land certificates, 17 cases related to licensing, 37 cases related to levies, and 3 cases related to retirement decisions. If the 
acquisition of cases or cases with evidence as explained above, compared with the budget allocation that must be issued by the State is really inefficient.

Need to increase Low enforcement. The authority of the Saber Pungli Task Force in the context of enforcing the law is as follows: 1. Building a system of preventing and combating illegal payments; 2 . Collecting data and information from ministries / institutions and other parties related to using information technology; 3 . Coordinate, plan, and carry out illegal eradication activities; 4. Perform hand catching operations; 5. Providing recommendations to the heads of ministries / institutions and heads of local governments to impose sanctions on extortion actors in accordance with the provisions of the legislation; 6 . Provide recommendations for the formation and execution of duties of extortion saber units in each public administration agency to the leadership of ministries / institutions and heads of regional governments; and 7. Carry out an evaluation of eradication of illegal fees. And all of these have been carried out with consistent and legal certainty, or indiscriminately.

The existence of this policy the State must budget of Rp. 3,000,000,000.00 (three billion rupiah) although what is able to be absorbed is Rp. 682,846,968, 00 (six hundred eighty two million eight hundred forty six thousand nine hundred sixty eight rupiah). (Source: East Java Regional Police Irwasda: Coordination Meeting for Illegal Eradication Unit in East Java Province 2017 Budget Year. Thus the case of arrest of illegal levies does not enter into a criminal act of corruption but is a general crime.

\section{References}

Charles O Jones, 1970, An Introduction to the Study of Public Policy, Belmont, CA: Wadswort

Fadillah, 2001, Prinsip-Prinsip Perumusan Kebijakan Negara. Jakarta, Sinar Grafika.

Riant Nugroho D, 2003, Reinventing Pembangunan, Jakarta: Gramedia Elex Media Komputendo).

CFG. Sunaryati Hartono, SH, et all, 2003, Panduan Investigasi untuk Ombudsmen Indonesia, Jakarta: Komisi Ombudsmen Nasional.

Santoso, 1992, Analisa Kebijakan Publik, PT. Tiara Wacana, Yogyakarta.

Thomas R. Dye, 1953, The Political System, New York: Knopf. 
Wuryanto, Doody, 2001, Panduan Rakyat Memberantas korupsi, Bandar Lampung: Komite Anti Korupsi 